\title{
Participation in Decision Making and Teachers' Commitment: A Comparative Study between Public and Private Secondary Schools in Arusha Municipality, Tanzania
}

\author{
Baraka Manjale Ngussa $^{1, *}$, Luicensi Gabriel ${ }^{2}$ \\ ${ }^{1}$ Senior Lecturer of Curriculum and Teaching, University of Arusha, Tanzania \\ ${ }^{2}$ Ward Educational Officer, Arusha District Council, Tanzania \\ *Corresponding author: ngussathe5th@gmail.com
}

\begin{abstract}
This study sought to find out about participation in decision making and teachers' commitment among secondary schools in Arusha city. It employed descriptive comparative design. A total of 159 teachers filled the questionnaires whose reliability was established through pilot study before actual data collection (See appendices). The study concluded that there is significant relationship between participation in decision-making and teachers' commitment. Teachers are committed to the success of their schools and they are emotionally attached to their career. However, teachers' commitment and participation in decision-making was higher in private schools than in public schools. Based on findings, it is recommended that school authorities should maximize participation in decision making in order to raise teachers' commitment.
\end{abstract}

Keywords: participation, commitment, decision, secondary schools, Arusha, Tanzania

Cite This Article: Baraka Manjale Ngussa, and Luicensi Gabriel, "Participation in Decision Making and Teachers' Commitment: A Comparative Study between Public and Private Secondary Schools in Arusha Municipality, Tanzania.” American Journal of Educational Research, vol. 5, no. 7 (2017): 801-807. doi: 10.12691/education-5-7-17.

\section{Introduction}

Participation in decision making and teachers' commitment are two sides of the same coin. They are important ingredients for proper functioning of organizations, including institutions of learning and secondary schools, particularly. Due to global competition, institutions are interested in organizational development and professional growth of employees through active participation in decision making and employees' commitment. While this is true in different types of organizations, it is also applicable in the institutions of learning. A range of authors have expressed the significance of both participative decision making and employees' commitment. According to Sull [20], for instance, commitment refers to any action taken in the present that aims at positive future course of action in a given organization. According to Robinson [16], commitment is a feeling of obligation or emotional attachment to the job. Organizational commitment is further described as a strong belief in and acceptance of the organization's goals and values. It depicts willingness to exert considerable effort on behalf of the organization and strong desire to attain organizational goals.

Employee commitment is very essential in secondary school settings. This is because it is only when teachers are committed, when they will be able to combine their efforts to see to it that schools operate effectively and in that way learning performance will be maximized. This is supported by Swarnalatha [21] who argues that committed teachers strive more for better students' performance. According to Sen [18], teachers' participation in decision-making helps the school administration to achieve organizational objectives. According to Ojwuku [13], tteachers' getting together to make decisions can bring about school transformation and positive changes. While there are many factors that can contribute to employees' commitment in the organizations, participation in decision making is a factor that cannot be ignored. It is in the light of this fact that this study sought to investigate on participation in decision making and teachers' commitment among secondary schools in Arusha Municipality.

The study was guided by the following research questions: (1) What is the level of teachers' participation in decision-making among secondary school in Arusha Municipality? (2) Is there significant difference in the level of teachers' participation in decision-making between Public and Private Secondary Schools in Arusha Municipality? (3) What is the level of teachers' commitment among secondary school teachers in Arusha Municipality? (4) Is there significant difference in the level of teachers' Commitment between Public and Private Secondary Schools in Arusha Municipality? (5) Is 
there significant relationship between participation in decision-making and teachers' commitment?

\section{Review of Related Literature and Studies}

Review of related literature and studies was organized into two major sections namely teachers' participation in decision making and teachers' commitment. .

\subsection{Teachers' Participation in Decision- Making}

Participation in decision making is of prime importance for effective school management. But teachers, in most cases, have been excluded in the process of decision making. This is revealed by Muindi [10] who conducted a research in Kenya and came up with findings that decision-making on school staffing, curriculum and resource allocation had been made by school principals or selected members of administrative managerial teams. The study also established that in most cases, teachers were usually excluded by school administrators in the process of decision-making. Contrary to this trend, researchers have indicated significance of teachers' participation in decision making. Sen [18] for instance, contends that teachers' participation in decision-making helps the school administration to achieve organizational objectives. Njideka [12] recommended that managers should increase the frequency and level of teachers' participation in decision-making because they are the ones carrying out the main operative work and they are in the better position to know what goes on in school operations.

According to Murphy, David and Brown as cited in Keung [3], teachers' participation in decision-making improves job satisfaction and commitment, which are positive indicators for effective management. While there are many areas in which teachers can be involved in decision making, schools can particularly encourage and open avenues for teachers to participate in activities outside the classroom such as textbook selection, curriculum development, learning assessment, student placement, personnel staffing and professional development [6]. This is because teachers who participate in decision-making are expected to make more sincere efforts to implement those decisions [13]. Through collaborative decision making approach, teachers benefit from one another's experiences and enhance their teaching effectiveness by offering constructive suggestions and appropriate feedbacks to each other. Teachers' getting together to make decisions can bring about school transformation and positive changes.

According to Wadesango [22], teachers need the opportunity and space to participate in decision-making at a level that satisfies their needs. This is because those who participate in the decisions of the organization, feel like they are a part of a team with a common goal, and find their sense of self-esteem and creative fulfillment heightened. Therefore, teacher participation approach can be used as a tool to enhance relationships in the organization, to increase employee work incentives and to increase the rate of information circulation across the organization.

Participation in decision-making gives teachers the opportunity to voice their opinions, and to share their knowledge with both school administrators and fellow teachers. While this improves the relationship between school leaders and teachers, it also encourages a strong sense of teamwork among teachers. According to Omobude [14], participation in decision-making is a good way for school administrators to gather information about the teachers as to how they work and where training may be necessary, both of which leading to an increased effectiveness and ultimately good teamwork and performance. The findings of Muindi [11] in Kenya indicate a significant strong and positive correlation to exist between job satisfaction and participation in decision-making. Since job satisfaction is important for teaching effectiveness, participation in decision-making becomes an important factor for school effectiveness.

Wainaina [23] conducted a research about effect of teachers' participation in decision making on the organizational commitment amongst academic staff in the private and public universities in Kenya and found that decisions made in consultation with teachers are more effective. Particularly, those teachers who are involved in decision-making are better equipped to implement such decisions. Similarly, the study of Omobude [14] revealed that private school teachers participate more in decision-making than public school teachers. Teachers in private schools are given more involvement in the decision-making.

Moshet [9] conducted a research about teacher participation in school decision-making and job satisfaction as correlates of organizational commitment in senior schools in Botswana and found that allowing teacher participation in decision-making results into a more satisfied teacher with greater commitment to organizational goals.

\subsection{Teachers' Commitment}

Organizational commitment involves people's feelings about the organizations for which they work and the degree to which they identify with the organizations that employ them. Those committed to their work have intrinsic drives and aspiration toward higher output [8]. The importance of teachers' commitment is brought to view by the fact that committed teachers strive more for better students' performance [21]. A committed individual usually will have a sense of responsibility, involvement, loyalty and ownership towards something [15]. A series of studies have been consulted to throw light on the essence of teachers' commitment. Brown [1], for instance, concluded that teachers' commitment and loyalty are central features for better performance.

Studies indicate variation in commitment between those of public and private secondary schools. Particularly, teachers in private schools are more committed than teachers in public schools. Similarly, Khan [4], for instance, conducted research about Organizational Commitment among Public and Private School Teachers in India to determine their overall organizational commitment. The findings indicate that private school teachers are more committed as compared to public school 
teachers. Shabbir [19] conducted a similar study and his findings indicate that private school teachers are more committed to their work and spend more time in teaching activities whereas in public sector schools, absenteeism and lateness trends are found in teachers. Private school's teachers plan and practice more teaching activities such as lesson planning, usage of instruction materials, homework routine, regular assessment, arrangement of class tests and reviews as compared to public schools teachers. According to Zubair [25], organizational commitment has positive influence on teachers' creativity. Sagvandy and Omidian [17] showed that involvement in managerial and curricular decisions was associated with job satisfaction, and involvement in curricular decisions was associated with commitment.

\section{Research Methodology}

This study employed descriptive comparative research design. Williams [24] assert that the descriptive research approach is a basic research method that examines the situation as it exists in its current state. Descriptive research involves identification of attributes of a particular phenomenon based on an observational basis, or the exploration of correlation between two or more phenomena. This design was appropriate to the study because it is based on surveying and finding facts by inquiry for the purpose of describing the correlation between participation in decision-making and teachers' commitment. In this study the population was teachers from 17 private schools and 26 public secondary schools. The sample of the study was selected by using systematic randomly sampling. The researcher took $25 \%$ of teachers from public schools and $50 \%$ of teachers from private schools because number of teachers in public schools was greater than those in private schools. A total of 159 teachers including 87 from public schools and 52 from private schools were selected as sample space to fill the questionnaires. Teachers who filled the questionnaire and returned to the researcher were 136 where as 52 were males equal to $38.2 \%$ and 84 were females equal to $61.8 \%$. These respondents were of different types in terms of gender and type of school. Respondents were also categorized according to nature of school whereby majority of them were from public schools (56.6\%) while those from private schools were $43.4 \%$.

For validity, the researcher ensured that objectives of the study were clearly defined and operationalized.
Reliability of the questionnaire was established through a pilot study whereby 36 teachers from one secondary school, in Arusha city participated by filling the questionnaire. Questionnaire responses were coded into the statistical package for social sciences program and Cronbach's Alpha was used to measure reliability of individual items in the questionnaire. The cut off point for reliability was set to be 0.6 Cronbach's Alpha. The Cronbach's Alpha ranged between 0.616 and 0.819, meaning that the questionnaire was reliable.

\section{Presentation, Analysis, Interpretation and Discussion}

This section presents, analyzes and interprets findings of the study about a correlation between teachers' participation and teachers' commitment in secondary schools under investigation.

Analysis of data was done according to research questions. There were five research questions which guided this study. Both inferential and descriptive statistics were used to analyze data. Descriptive statistics was used to determine mean scores and standard deviation of responses under the following interpretation: 3.50-4.00 $=$ Strongly Agree, 2.50-3.49 = Agree, 1.50-2.49= Disagree and 1.00-1.49 = Strongly Disagree. Inferential statistics was used to test hypotheses that germinated from the research questions.

1. What is the level of teachers' participation in decisionmaking among secondary school teachers in Arusha Municipality?

This research question called for establishment whether teachers participate in decision making. In order to answer this question, there were 10 items which teachers were needed to respond to as seen in Table 1 . The mean score of respondents in all items ranged between 2.50 and 3.49 meaning they agreed to all statements. Particularly, respondents agreed that School leaders are available to them when they have questions or need help $(M=3.0074$, $\mathrm{SD}=.67466$ ), teachers regularly share and exchange ideas with school administration $(\mathrm{M}=2.9926, \quad \mathrm{SD}=64974$, teachers are given control over their work by school leaders $(\mathrm{M}=2.9776, \mathrm{SD}=.71458)$, school leaders accept teachers as valuable partners in making decisions $(\mathrm{M}=2.9632, \mathrm{SD}=70352)$ and teachers are involved in important decisions that affect them $(\mathrm{M}=2.9559$, $\mathrm{SD}=$.76853).

Table 1. Participation of Teachers in Decision-making

\begin{tabular}{|c|c|c|c|c|}
\hline SN & Item & Mean & STD. Dev & Interpretation \\
\hline 1. & School leaders are available to me when I have questions or need help & 3.0074 & .67466 & Agree \\
\hline 2. & Teachers regularly share and exchange ideas with school administration & 2.9926 & .64974 & Agree \\
\hline 3. & Teachers are given control over their work by school leaders & 2.9779 & .71458 & Agree \\
\hline 4. & School leaders accept employees as valuable partners in making decision & 2.9632 & .70352 & Agree \\
\hline 5. & Teachers are involved in important decisions that affect them & 2.9559 & .76853 & Agree \\
\hline 7. & I am satisfied with the level of teachers’ involvement in decision making & 2.911 & .7577 & Agree \\
\hline 8. & Teacher's opinions are always taken into consideration by school leaders & 2.8750 & .74473 & Agree \\
\hline 9. & School leaders are willing to share decision-making power with teachers & 2.8382 & .70154 & Agree \\
\hline 10. & Teachers are involved in formulating school's policies. & 2.8296 & .75844 & Agree \\
\hline
\end{tabular}


These findings are worth noting because participation in decision making is an important factor for effective functioning of the school. This is supported by the study findings of Kumbi [5] who conducted research about teachers' participation in school decision-making in secondary schools of Arsi Zone and found that absence of participatory school leadership, lack of trust between teachers and principals, lack of training and support, lack of commitment, and absence of motivation were some of the factors that were found to have impeded teachers' participation in school decision-making.

Respondents also agreed that school administration consults teachers before decisions are made $(\mathrm{M}=2.9179$, $\mathrm{SD}=.73626)$, they are satisfied with the level of teachers' involvement in decision-making $(\mathrm{M}=2.911, \mathrm{SD}=.7577$, their opinions are always taken into consideration by school leaders $(\mathrm{M}=2.8750, \mathrm{SD}=.74473)$, school leaders are willing to share decision-making power with teachers $(\mathrm{M}=2.8382, \mathrm{SD}=70154)$ and that teachers are involved in formulating school's policies $(\mathrm{M}=2.8296, \mathrm{SD}=.75844)$. These findings show teachers agree that there is participation in decision-making in Arusha City Secondary Schools. Most of the respondents agreed that School leaders are available when they are needed for help. This can be seen in item number one $(M=3.0074$, $\mathrm{SD}=.67466)$. School leaders must ensure maximum involvement of teachers in decision-making so as to ensure maximum outcome. Level of participation in decision-making for the teachers under investigation is therefore appropriate.

When teachers are involved in making decisions, they gain a professional and personal stake in the organization and its overall success.

2. Is there significant difference in the level of teachers' participation in decision-making between Public and Private Secondary Schools in Arusha Municipality?

The second research question sought to establish difference in the level of participation in decision-making by teachers categorized according to nature of their schools, particularly public and private schools. This research question called for testing of a null hypothesis which states: Ho1: there is no significant difference in the level of teachers' participation in decision-making between Public and Private Secondary Schools in Arusha City.

This hypothesis was tested through independent sample t-test as reflected in Table 2 and Table 3 in order to determine the difference, if any. As Table 2 indicates, teachers from private secondary schools had higher mean score $(\mathrm{M}=3.1331, \mathrm{SD}=.47729)$ in decision-making participation as compared to teachers from public secondary schools who had the mean score of 2.7678 .

The Sig of 0.00 in Table 3 , which is greater than the critical value $(p=0.05)$ suggests that the mean score difference is significant, thus, we come to a conclusion that there is a significant difference in teachers participation in decision-making between public and private secondary schools. Teachers in private schools are more involved in decision-making than teachers from public schools. Thus, the null hypothesis that there is no significant difference in the level of teachers' participation in decision-making between Public and Private Secondary Schools in Arusha City is rejected. These findings are further supported by the findings of Najjar [11] who assert that teachers in public schools consider themselves less concerned about the schools decisions and appear to feel less responsible for such decisions. In private schools social collaboration is the dominant feature and is very well established as a tool to reach destination.

3. What is the level of teachers' commitment among secondary school teachers in Arusha Municipality?

In order to answer this question, there were 10 items which respondents were needed to respond to as seen in Table 4.

Table 2. Group Statistics for Participation in Decision-making

\begin{tabular}{|c|c|c|c|c|c|}
\hline & Type of School & N & Mean & Std. Deviation & Std. Error Mean \\
\hline \multirow{2}{*}{ PARTICIPATION } & Public & 77 & 2.7678 & .33514 \\
\cline { 2 - 5 } & Private & 59 & 3.1331 & .03819 \\
\hline
\end{tabular}

Table 3. Independent sample T-test for Teachers' Participation

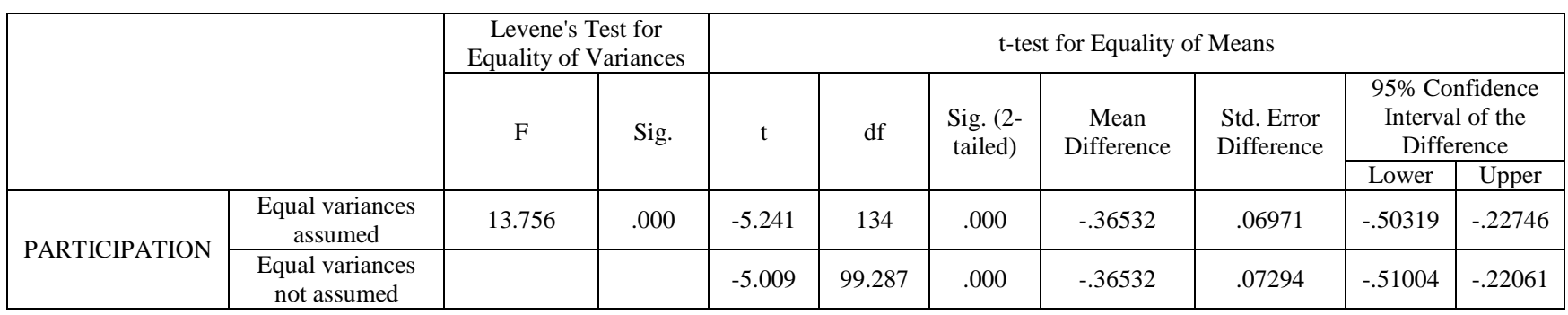

Table 4. Commitment of Teachers

\begin{tabular}{|c|c|c|c|c|}
\hline SN & Item & Mean & STD. Dev & Interpretation \\
\hline 1. & Teachers are accountable for their works & 3.0809 & .69979 & Agree \\
\hline 2. & School administrators exercise loyalty in the school & 3.0368 & .66006 & Agree \\
\hline 3. & Teachers are committed to the success of this school & 2.9925 & .61920 & Agree \\
\hline 4. & Teachers are productive in their activities & 2.9704 & .65723 & Agree \\
\hline 5. & Teachers are emotionally attached in their career & 2.9104 & .69868 & Agree \\
\hline 6. & Teachers feel moral obligation to remain in this school & 2.9030 & .83953 & Agree \\
\hline 7. & Teachers efforts are valued in this school & 2.8741 & .72719 & Agree \\
\hline 8. & School environment convincing teachers to perform better & 2.8712 & .81405 & Agree \\
\hline 9. & Teachers expectation are compatible with the school's goals and policies & 2.8626 & .74176 & Agree \\
\hline 10. & School administrators are aware of the needs of their teachers & 2.8358 & .74787 & Agree \\
\hline
\end{tabular}


The mean score of respondents to all items ranged between 2.50 and 3.49 meaning that they agreed to all statements. Particularly, respondents agreed that teachers are accountable for their works $(M=3.0809, \mathrm{SD}=.69979)$, school administrators exercise loyalty in the schools $(\mathrm{M}=3.0368, \mathrm{SD}=.66006)$, teachers are committed to the success of their schools $(\mathrm{M}=2.9925, \mathrm{SD}=.61920)$, teachers are productive in their activities $(\mathrm{M}=2.9704, \mathrm{SD}=.65723)$ and they are emotionally attached to their career $(\mathrm{M}=2.9104, \mathrm{SD}=.69868)$. The findings of Mart [7] who conducted a similar research about tteachers' Commitment and Dedication to Student Learning in Erbil-Iraq found that factors that decide teachers' commitment and dedication degree are: interaction between teachers, teacher-student relationship, the quality of the work teachers do at school, the compatibility of school administration. Teachers who have commitment to school display such attitudes as: being proud of the school he works for, evoking a desire to work harder, being interested in the future of the school. Furthermore, teachers agreed that they feel moral obligation to remain in their schools $(\mathrm{M}=2.9030, \mathrm{SD}=.83953)$, their efforts are valued in the schools $(\mathrm{M}=2.8741, \mathrm{SD}=.72719)$, school environment convinces teachers to perform better $(\mathrm{M}=2.8712, \mathrm{SD}=.81405)$, teachers' expectations are compatible with school goals and policies $(M=2.8626$, $\mathrm{SD}=.74176)$ and that school administrators are aware of the needs of their teachers $(\mathrm{M}=2.8358, \mathrm{SD}=.74787)$.

These findings shows that teachers in Arusha city are committed to their work as the lowest score is $(\mathrm{M}=28358$, $\mathrm{SD}=24787)$ and the highest $(\mathrm{M}=30809, \mathrm{SD}=69979)$ which range within the agreement zone. Teachers who are committed to their students and feel responsible for their learning show a strong sense of efficacy. This is supported by the study findings of Frenette and Ching [2] who conducted a research in Canada about Academic Outcomes of Public and Private High School Students and found that a teacher who is truly committed to students is one that puts students' learning and interests above everything else.

4. Is there significant difference in the level of teachers' Commitment between Public and Private Secondary Schools in Arusha Municipality?

The fourth research question sought to establish difference in the commitment of teachers categorized according to nature of their schools, particularly public and private schools. This research question called for testing of a null hypothesis which states: Ho1: there is no significant difference in the level of teachers' commitment between Public and Private Secondary Schools in Arusha City.

This hypothesis was tested through independent sample t-test as reflected in Table 5 and Table 6 in order to determine the difference, if any.

As it can be seen in Table 5 the mean score of teachers from private schools is higher $(3.1637, \mathrm{SD}=.40697)$ than that of teachers from public schools $(M=2.7541$, $\mathrm{SD}=.37787$ ) meaning commitment of teachers from private schools is comparatively higher than that of teachers from public schools. The Sig of .000 in Table 6 further suggests that the mean score difference is significant and therefore we reject the null hypothesis and maintain that there is a significant difference in the level of teachers' commitment between Public and Private Secondary Schools in Arusha City.

5. Is there significant relationship between participation in decision-making and teachers' commitment?

The fifth research question sought to establish relationship between the independent variable namely participation in decision-making and the dependent variable namely teachers' commitment. This research question called for testing of a null hypothesis which states:

Ho1: there is no significant relationship between participation in decision-making and teachers' commitment.

This hypothesis was tested through Pearson Product Moment Correlational Coefficient as reflected in Table 7.

Table 5. Group Statistics for Teachers' Commitment

\begin{tabular}{|c|c|c|c|c|c|}
\hline & Type of School & $\mathrm{N}$ & Mean & Std. Deviation & Std. Error Mean \\
\hline \multirow{2}{*}{ COMMITMENT } & Public & 77 & 2.7541 & .37787 & .04306 \\
\cline { 2 - 6 } & Private & 59 & 3.1637 & .40697 & .05298 \\
\hline
\end{tabular}

Table 6. Independent Sample t-test for teachers' commitment

\begin{tabular}{|c|c|c|c|c|c|c|c|c|c|c|}
\hline & & $\begin{array}{r}\text { Leven } \\
\text { Equality }\end{array}$ & $\begin{array}{l}\text { st for } \\
\text { iriances }\end{array}$ & \multicolumn{7}{|c|}{ t-test for Equality of Means } \\
\hline & & \multirow{2}{*}{1 . } & \multirow[t]{2}{*}{ Sig. } & \multirow[t]{2}{*}{$\mathrm{t}$} & \multirow[t]{2}{*}{ df } & \multirow[t]{2}{*}{$\begin{array}{l}\text { Sig. (2- } \\
\text { tailed) }\end{array}$} & \multirow[t]{2}{*}{$\begin{array}{c}\text { Mean } \\
\text { Difference }\end{array}$} & \multirow[t]{2}{*}{$\begin{array}{l}\text { Std. Error } \\
\text { Difference }\end{array}$} & \multicolumn{2}{|c|}{$\begin{array}{l}\text { 95\% Confidence } \\
\text { Interval of the } \\
\text { Difference }\end{array}$} \\
\hline & & & & & & & & & Lower & Upper \\
\hline \multirow{2}{*}{ COMMITMENT } & $\begin{array}{c}\text { Equal variances } \\
\text { assumed }\end{array}$ & 5.699 & .018 & -6.058 & 134 & .000 & -.40958 & .06760 & -.54329 & -.27587 \\
\hline & $\begin{array}{c}\text { Equal variances not } \\
\text { assumed }\end{array}$ & & & -5.999 & 119.979 & .000 & -.40958 & .06828 & -.54476 & -.27440 \\
\hline
\end{tabular}

Table 7. Correlations between participation in Decisions and Commitment

\begin{tabular}{|c|c|c|c|}
\hline & & PARTICIPATION & COMMITMENT \\
\hline \multirow{3}{*}{ PARTICIPATION } & Pearson Correlation & 1 & $.556^{* *}$ \\
\hline & Sig. (2-tailed) & & .000 \\
\hline & $\mathrm{N}$ & 136 & 136 \\
\hline \multirow{3}{*}{ COMMITMENT } & Pearson Correlation & $.556^{* *}$ & 1 \\
\hline & Sig. (2-tailed) & .000 & \\
\hline & $\mathrm{N}$ & 136 & 136 \\
\hline
\end{tabular}

**. Correlation is significant at the 0.01 level (2-tailed).. 
As Table 7 indicates, there is a moderate significant relationship (Pearson Correlation $=.556$, Sig. (2-tailed $=.000$ ) between teachers' participation in decision-making and teachers, commitment. This type of relationship is positive in nature meaning as one variable increases, the other variable also increases. Thus, the more teachers participate in decision-making, the more committed they are. Therefore, we reject the null hypothesis and maintain that there is a significant relationship between participation in decision-making and teachers' commitment. This implies that participation in decisionmaking increases teachers' commitment.

\section{Conclusions and Recommendations}

\subsection{Conclusions}

In the context of teachers' participation in decisionmaking and their commitment, it was concluded that:

- School leader's share and exchange ideas with teachers so as to improve communication.

- Teachers are given control over their work and they are involved in important decisions that affect their daily activities.

- There is existence of participation in decision making in the form of sharing and exchange of ideas and consultation. However, participation in decision-making was higher in private school than in public schools.

- Teachers are committed to the success of their schools and they are emotionally attached to their careers. However, commitment of teachers was higher in private than in public schools.

- There is significant positive correlation between participation in decision-making and teachers' commitment. This implies that when teachers participate in decision-making, their levels of commitment increase.

\subsection{Recommendations}

Based on the findings and conclusions of this study, it is recommended that tteachers should be given more opportunities to come together and share different ideas and experiences with school administration. Particularly, they should participate in decision-making in such issues as budget planning and policy formulation. Secondly, school leaders should increase teachers' commitment by providing opportunities for teacher to participate in various decisions.

\section{References}

[1] Brown, S. (2011). Workplace Performance, Worker Commitment and Loyalty. Institute for the Study of Labor.

[2] Frenette, M and Ching, P (2015). Academic Outcomes of Public and Private High School Students: What Lies Behind the
Differences? Logo for Analytical Studies Branch Research Paper Series. Social Analysis and Modeling Division, Statistics Canada.

[3] Keung, C.C (2002). Teacher Participation in Decision-making of Secondary School. Hong Kong Institute of Education.

[4] Khan S. (2015). Organizational Commitment among Public and Private School Teachers. The International Journal of Indian Psychology 2(3) 451-502.

[5] Kumbi, J.H (2015). Teachers' Participation in School Decisionmaking in Secondary Schools. Journal of education and behavioral science 11(23) 343-476.

[6] Lin, J.Y., (2014). Teacher Involvement in School Decisionmaking. Journal of Studies in Education, (4(3), 123-125.

[7] Mart, T.C., (2013). A Passionate Teacher: Teacher Commitment and Dedication to Student Learning International Journal of Academic Research in Progressive Education and Development January 2013, Vol. 2(1), 226-348.

[8] Meyer, J., and Allen, N. (1997). Commitment in the Workplace: Theory, Research, and Application. Sage Publications.

[9] Moshet, A.P (2013). Teacher Participation in School DecisionMaking. Job Satisfaction as Correlates of Organizational Commitment in Senior Schools in Botswana. Andrews University Digital Library.

[10] Muindi, K. F. (2011). The Relationship between Participation in Decision-making and Job Satisfaction. Journal of Human Resources Management Research, 16(11), 98-123.

[11] Najjar, D. (2008). Effectiveness of management in private schools in Lebanon. School of education.

[12] Njideka, P. E., (2011). Participation in Decision-making and its Impact on Productivity: An Appraisal of Government Printing Press.

[13] Ojukuku, R. M., \& Sajuyigbe, A. S. (2014). Effect of Teachers Participation in Decision-making on their commitment, Journal of educational Management, 6(10), 211-233.

[14] Omobude, M and Igbudu, U., (2012). Influence of Teachers Participation in Decision-making on Their Job Performance in Public and Private Secondary Schools. European Journal of Business and Social Sciences (1)5 117-166.

[15] Raman, A. et al (2105). Relationship between Principals' Transformational Leadership Style. And Secondary School Teachers' Commitment. Asian Social Science program.

[16] Robinson, D., Perryman, S. and Hayday, S. (2003). The Drivers of Teachers Engagement. Institute for Employment Studies.

[17] Sagvandy, S R, and Omidian F (2015). Teachers' participation in different levels of decision making in council and developing professional skills. World Scientific News. Journal of Education and Training 3(17) 122-156.

[18] Sen, R. (2012). Teachers' participation in India. Principals and Teachers Relationship. International journal of education, 3(40), 45-50.

[19] Shabbir, M., Wei S. Guang. Y 2014. A Comparative Study of Public and Private Primary Schools, with Perspective of Practice of Effective Teaching Activities and Outcomes International Journal of Advanced Research.2 (6).

[20] Sull, D. (2003). Organizational Culture. Managing by Commitments. Harvard Business Review, 5(6), 101-105.

[21] Swarnalatha, S.S. (2016). Work Commitment of Secondary School Teachers. International Journal of Indian Psychology, 3(4), 99-156.

[22] Wadesango, N. (2012). The Influence of Teacher Participation in Decision-making on their Occupational Morale. Walter Sisulu University, East London. Republic of South Africa.

[23] Wainaina, L., Iravo, M \& Waititu, A. (2014). Effect of Teachers Participation in Decision Making on the Organizational Commitment Amongst Academic Staff in the Private and Public Universities in Kenya. International Journal of Advanced Research in Management and Social Sciences, 5(18), 278-292.

[24] Williams, C (2007). Research Methods. Journal of Business \& Economic Research, 5(3), 76.

[25] Zubair, A. (2015). Teachers' Participation in Decision-making and Manager's Encouragement of Creativity. The Mediating Role of Climate for Creativity and Change. Journal of Service Science and Management, 8(12), 306-321. 


\section{Appendix: RELIABILTY ANALYSIS}

\section{PARTICIPATION IN DECISION-MAKING}

Reliability Statistics

\begin{tabular}{|l|l|}
\hline Cronbach's Alpha & N of Items \\
\hline .819 & 10 \\
\hline
\end{tabular}

\begin{tabular}{|c|c|c|c|c|}
\hline \multicolumn{5}{|l|}{ Item-Total Statistics } \\
\hline & $\begin{array}{l}\text { Scale Mean if } \\
\text { Item Deleted }\end{array}$ & $\begin{array}{l}\text { Scale Variance } \\
\text { if Item Deleted }\end{array}$ & $\begin{array}{l}\text { Corrected Item- } \\
\text { Total Correlation }\end{array}$ & $\begin{array}{l}\text { Cronbach's Alpha } \\
\text { if Item Deleted }\end{array}$ \\
\hline $\begin{array}{l}\text { School leaders are willing to share decision-making power with } \\
\text { teachers }\end{array}$ & 25.7429 & 12.550 & .631 & .788 \\
\hline $\begin{array}{l}\text { School leaders accept employees as valuable partners in making } \\
\text { decision }\end{array}$ & 25.7429 & 12.432 & .730 & .780 \\
\hline Teachers are involved in important decisions that affect them & 25.7429 & 12.197 & .660 & .784 \\
\hline $\begin{array}{l}\text { Teachers regularly share and exchange ideas with school } \\
\text { administration }\end{array}$ & 25.7143 & 13.210 & .491 & .803 \\
\hline School leaders are available to me when I have questions or need help & 25.6571 & 13.879 & .293 & .824 \\
\hline School administration consults teachers before decisions are made & 25.9143 & 12.316 & .592 & .792 \\
\hline $\begin{array}{l}\text { I am satisfied with the level of teachers' involvement in decision- } \\
\text { making }\end{array}$ & 25.8571 & 13.303 & .483 & .804 \\
\hline $\begin{array}{l}\text { Teachers' opinions are always taken into consideration by school } \\
\text { leaders }\end{array}$ & 25.6286 & 13.829 & .408 & .811 \\
\hline Teachers are given control over their work by school leaders & 25.6000 & 13.365 & .369 & .817 \\
\hline Teachers are involved in formulating school's policies & 26.0571 & 13.232 & .404 & .813 \\
\hline
\end{tabular}

\section{COMMITMENT OF TEACHERS}

\begin{tabular}{|l|l|}
\hline \multicolumn{2}{|l|}{ Reliability Statistics } \\
\hline Cronbach's Alpha & N of Items \\
\hline .616 & 10 \\
\hline
\end{tabular}

\begin{tabular}{|l|c|c|c|c|}
\hline Item-Total Statistics & $\begin{array}{c}\text { Scale Mean if } \\
\text { Item Deleted }\end{array}$ & $\begin{array}{c}\text { Scale Variance if } \\
\text { Item Deleted }\end{array}$ & $\begin{array}{c}\text { Corrected Item- } \\
\text { Total Correlation }\end{array}$ & $\begin{array}{c}\text { Cronbach's Alpha } \\
\text { if Item Deleted }\end{array}$ \\
\hline Teachers are committed to the success of this school & 25.3235 & 4.710 & .232 & .604 \\
\hline Teachers are productive in their activities & 25.3235 & 4.650 & .326 & .583 \\
\hline Teachers are emotionally attached in their career & 25.4118 & 4.371 & .543 & .540 \\
\hline Teachers feel moral obligation to remain in this school & 25.6471 & 4.599 & .350 & .577 \\
\hline Teachers are accountable for their works & 25.5882 & 4.613 & .305 & .587 \\
\hline School administrators exercise loyalty in the school & 25.5294 & 4.620 & .344 & .579 \\
\hline Teachers efforts are valued in this school & 25.4118 & 5.219 & .109 & .622 \\
\hline School administrators are aware with the needs of their teachers & 25.6765 & 4.771 & .193 & .614 \\
\hline School environment convincing teachers to perform better & 25.6471 & 4.296 & .365 & .570 \\
\hline $\begin{array}{l}\text { Teachers expectation are compatible with the school's goals and } \\
\text { policies }\end{array}$ & 25.6176 & 4.668 & .171 & .626 \\
\hline
\end{tabular}

